
$\underbrace{}_{\mathrm{O} \text { B E| }} \mid \begin{aligned} & \text { JOURNAL OF } \\ & \text { BIOLOGY } \\ & \text { EDUTION }\end{aligned}$
E-ISSN 2656-3436/ P-ISSN 2615-3947
IAIN KUDUS
Tersedia online: http://journal.iainkudus.ac.id/index.php/jbe

\title{
Penggunaan Probiotik EM4 Terhadap Laju Pertumbuhan Ikan Lele (Clarias Sp) Dengan Dosis yang Berbeda
}

\author{
Zainuddin ${ }^{1}$, Awaludin', Atika Okta Melisa ${ }^{3}$, Acay $^{4}$, \\ ${ }^{1,2,4)}$ Program Studi Akuakultur Universitas Borneo Tarakan \\ ${ }^{3)}$ Program Studi Tadris Biologi IAIN Kudus
}

\begin{abstract}
ABSTRAK
Penelitian penggunaan probiotik EM4 dengan dosis yang berbeda terhadap pertumbuhan ikan lele dilakukan di Mini Hatchery Fakultas Perikanan dan Ilmu Kelautan Universitas Borneo Tarakan tahun 2019. Tujuan penelitian ini adalah untuk mengetahui penggunaan probiotik EM4terhadap laju pertumbuhan ikan lele (Clarias sp)dengan dosis yang berbeda dengan ukuran bibit lele $4-5 \mathrm{~cm}$. Penelitian ini menggunakan rancangan acak lengkap (RAL) 4 perlakuan dan 3 ulangan. A (kontrol), B (10 ml/kg pakan), C (20 ml/kg pakan) dan D (30 ml/kg pakan). Penelitian ini dilakukan selama 30 hari. Parameter yang diamati adalah pertumbuhan panjang dan berat, kelangsungan hidup, serta beberapa parameter kualitas air seperti suhu, pH, DO dan amoniak. Pengukuran pertumbuhan ikan lele dilakukan 2 kali hari pertama dan hari terakhir penelitian yang berlangsung 30 hari. Analisis data menggunakan ANOVA. Hasil penelitian menunjukan bahwa pemberian probiotik pada ikan lele dengan berbagai dosis tidak berbeda nyata pada setiap perlakuan ,tetapi perlakuan D pakan pellet dengan Dosis probiotik $30 \mathrm{ml} / \mathrm{kg}$ mengalami pertumbuhan berat dan pertumbuhan panjang yang lebih tinggi yaitu $2.22 \mathrm{gr}$ dan $1.22 \mathrm{~cm}$ jika dibandingkan dengan perlakuan lainnya.
\end{abstract}

Kata kunci : Probiotik EM4, pertumbuhan, kualitas air, benih ikan lele

\section{ABSTRACT}

Research on the use of EM4 probiotics with different doses on the growth of catfish was carried out at the Mini Hatchery of the Faculty of Fisheries and Marine Sciences, The University of Borneo Tarakan in 2019. The purpose of this study was to determine the use of EM4 probiotics on the growth rate of catfish (Clarias sp) with different doses with sizes $4-5 \mathrm{~cm}$. This study used a completely randomized design (CRD) with 4 treatments and 3 replications. A (control), B (10 $\mathrm{ml} / \mathrm{kg}$ feed $), C(20 \mathrm{ml} / \mathrm{kg}$ feed $)$ and $D(30 \mathrm{ml} / \mathrm{kg}$ feed $)$. This research was conducted for 30 days. Parameters observed were growth in length and weight, survival, as well as several water quality parameters such as temperature, pH, DO, and ammonia. The measurement of catfish growth was carried out 2 times on the first day and the last day of the study which lasted 30 days. Data analysis using ANOVA.The results showed that the administration of probiotics in catfish with various doses was not significantly different in each treatment, but treatment D pellet feed with a probiotic dose of $30 \mathrm{ml} / \mathrm{kg}$ experienced higher growth in weight and length growth, namely $2.22 \mathrm{gr}$ and $1.22 \mathrm{~cm}$ when compared to the treatment. other.

Keywords: commercial probiotics, growth, water quality, catfish fry 


\section{PENDAHULUAN}

Indonesia memiliki potensi yang cukup besar untuk dimanfaatkan sebagai lahan budidayaikan, apabila dibandingkan dengan luas perairan Indonesia, karena Indonesia merupakan negara maritim, sehingga luas perairan lebih besar disbanding dengan daratan.Sumber daya alam perairan Indonesia belum termanfaatkan dengan baik. Salah satunya adalah hasil budidaya ikan air tawar di Indonesia yang belum dimanfaatkan secara maksimal. Perairan tawar yang biasa dan dapat dimanfaatkan untuk budidaya ikan meliputi sungai, rawa, dan danau (Maryanto dan Ubaidillah, 2003).

Budidaya perikanan di Indonesia memiliki beberapa teknik budidaya, salah satunya adalah akuakultur. Akuakultur merupakan teknik untuk mendapatkan produksi guna memenuhi kebutuhan manusia. Usaha budidaya ikan membutuhkan teknik manajemen tertentu. Untuk mendapatkan hasil panen yang baik kita perlu memperhatikan tahapan-tahapan dalam budidaya ikan yang dimulai dari persiapan, tahap pemeliharaan, pemanenan, dan teknologi pasca panen. Berbagai teknik untuk menunjang keberhasilan budidaya meliputi menjaga kualitas air, mengendalikan penyakit, dan pemberian pakan optimal.

Ikan lele sebagai komoditas perikanan dengan nilai ekonomis tinggi belum dibudidayakan secara benar sehingga perlu diteliti mengenai teknik budidaya agar dapat memenuhi kebutuhan pasar, sehingga diperlukan adanya penelitian untuk mengantisipasi factorfaktor kegagalan produksi terutama tahap manajemen pakan. Pakan merupakan salah satu unsur penting dalam kegiatan budidaya yang menunjang pertumbuhan dan kelangsungan hidup ikan budidaya. Pakan pada kegiatan budidaya umumnya adalah pakan komersial yang menghabiskan sekitar 60-70\% dari total biaya reproduksi yang dikeluarkan (Gunawan, 2015). Hal inilah yang menyebabkan pentingnya pakan sehingga perlu dilakukan penelitian untuk memperbaiki nilai nutrisi pakan dengan penambahan probiotik.

Probiotik menurut Fuller (1987) adalah produk yang tersusun oleh mikroba atau pakan alami mikroskopik yang bersifat menguntungkn karena mampu meningkatkan keseimbangan mikroba pada saluran usus hewan inang. Wang et al (2008) dalam Ahmadi, et al (2008) menjelaskan bahwa bakteri propiotik menghasilkan enzim yang mampu mengurai senywa kompleks menjadi sederhana sehingga siap digunakan ikan. Dalam meningkatkan nutrisi pakan, bakteri yang terdapat dalam probiotik memiliki mekanisme dalam pembentukan beberapa enzim yang dapat membantu menghidrolisis nutrien pakan (molekul kompleks), seperti memecah 
karbohidrat, protein dan lemak menjadi molekul yang lebih sederhana sehingga mempermudah proses pencernaan dan penyerapan dalam saluran pencernaan ikan (putra, 2010). Hal ini sesuai dengan pernyataan Dhinga (1993) bahwa probiotik bermanfaat dalam mengatur lingkungan mikroba pada usus, menghalangi mikroorganisme patogen usus, dan memperbaiki efisiensi pakan dengan melepas enzim yang membantu proses pencernaan makanan

Probiotik banyak digunakan oleh pembudidaya ikan untuk mendapatkan hasil panen yang maksimal. Tak terkecuali pada pembudidaya ikan lele. Banyak pembudidaya ikan lele yang menggunakan probiotik, baik untuk menjaga kesehatan kolam lele ataupun memacu pertumbuhan lele. Probiotik pada dasarnya merupakan larutan yang berisi mikroba atau bakteri hidup yang mengguntungkan bagi inang dalam hal ini adalah lele yang dibudidayakan. Menurut Santoso (2013) pemberian probiotik (EM4) pada pakan dapat meningkatkan pertumbuhan ikan lele dumbo (Clarias sp).

Berdasarkan penelitian pendahuluan didapatkan hasil bahwa penggunaan probiotik pada dosis optimum dalam pakan buatan bagi meninggkatkan pertumbuhan benih ikan lele belum diketahui, sehingga perlu dilakukan penelitian mengenai pengaruh pemberian probiotik terhadap pertumbuhan ikan lele (Clarias sp) dengan dosis yang berbeda. Penelitian ini bertujuan untuk mengetahui pertumbuhan ikan lele (Clarias sp) dengan menggunakan probitik EM4 yang dicampur dengan pakan buatan.Manfaat daripenelitianini memberikan informasi kegunaan probiotik yang dicampur dengan pakan untuk pertumbuhan ikan lele (Clarias sp).

\section{METODE PENELITIAN}

\section{Waktu dan Tempat}

Penelitian ini telah dilaksanakan pada tanggal Maret - Mei 2020, perlakuan dilaksanakan di Laboratorium Mini Hatchery Fakultas Perikanan dan Ilmu Kelautan, sedangkan pengukuran kualitas air dilakukan di Laboratorium Kualitas Air Fakultas Perikanan dan Ilmu Kelautan Universitas Borneo Tarakan.

\section{Alat dan Bahan}

Adapun alat dan bahan yang digunakan dalam penelitian adalah baskom, seser, toples, selang, aerator, $\mathrm{pH}$ meter, DO meter, kamera, timbangan, ikan lele (Clarias sp.), pellet buatan, probiotik EM4 dan air tawar. 


\section{Prosedur Penelitian}

Prosedur kerja terdiri dari beberapa tahapan yaitu, persiapan alat dan bahan, perlakuan dengan pemberian probiotik pada pakan, pengukuran parameter, dan analisis data sebagai berikut:

1.Persiapan alat dan bahan

Semua peralatan penelitian sebelum digunakan terlebih dahulu dibersikan atau diseterilkan baik alat yang digunakan seperti Toples, Thermometer, Aerator, timbangan digital sedangkan DO meter Dikalibrasi. Adapun bahan yang digunakan adalah benih ikan lele dengan ukuran 4-5 cm dengan padat penebaran 10 ekor per Toples, pakan yang digunakan ialah pakan Crumble FF-999dan probiotik yang digunakan ialah probiotik EM4 (merek dan catalog number). 2.Perlakuan pemberiaan probiotik EM4

Ikan yang digunakan yaitu lele dengan ukuran $4-5 \mathrm{~cm}$ padat penebaran 1 ekor/liter (Setiawan 2009) dalam volume air sebanyak 10 liter (Ahmadi,et al. 2012). Wadah yang digunakan toples volume 10 liter. Pakan yang digunakan yaitu Crumble FF-999. Dengan dosis 5\% dari berat tubuh (Gurisna 2008), frekuensi pemberian pakan 3 kali sehari pagi pukul 07.00 WITA, siang pukul 12.00 WITAdan sorepukul 18.00 WITA(Arif, et al. 2014). Pemberian probiotik EM4 dengan cara penambahan pada pakan (Ahmadi, et al. 2012). Perlakuan yang diuji coba yaitu: A tanpa penambahan probiotik EM4 (kontrol), B (Pakan Crumble dengan penambahan probiotik dengan dosis $10 \mathrm{ml} / \mathrm{kg}$ pakan), C (Pakan Crumble $20 \mathrm{ml} / \mathrm{kg}$ pakan), dan D (Pakan Crumble $30 \mathrm{ml} / \mathrm{kg}$ pakan). Pengukuran pertumbuhan benih ikan lele tersebut dilakukan 2 kali pada Awal penelitian dan diakhir penelitian selama proses penelitian yang berlangsung selama 30 hari.

Pada awal penebaran kondisi fisik dari semua benih ikan lele dalam keadaan sehat, yang diindikasi dengan kondisi benih yang berenang aktif dan agresif dan ukuran benih yang sama (4 - $5 \mathrm{~cm}$ ). Penambahan probiotik pada pakan dilakukan dengan cara mencampurkan probiotok EM4 sesuai dosis dengan air sebanyak 200ml. Selanjutnya disemprotkan pada pakan Crumble setelah itu dikeringkan selama 10 - 30 menit hingga kering. Penelitian ini menggunakan Rancanggan Acak Lengkap (RAL) sebanyak 4 perlakuan dan 3 pengulangan dengan wadah yang disiapkan sebanyak 12 buah dan tentukan secara acak, jenis pakan uji yang digunakan dalam penelitian ini adalah :

a. Perlakuan A pakan pellet (Kontrol) 
b. Perlakuan B pakan pellet dengan Dosis probiotik EM4 $10 \mathrm{ml} / \mathrm{kg}$

c. Perlakuan C pakan pellet dengan Dosis probiotik EM4 $20 \mathrm{ml} / \mathrm{kg}$

d. Perlakuan D pakan pellet dengan Dosis probiotik EM4 $30 \mathrm{ml} / \mathrm{kg}$

3.Pengukuran parameter

Parameter yang diukur selama penelitian antara lain pertumbuhan biomassa, laju pertumbuhan, panjang, kelangsungan hidup dan parameter kualitas air.

\section{a.Pengukuran Pertumbuhan Berat}

Untuk mengetahui pertumbuhan mutlak ikan nila di gunakan rumus menurut Zonneveld, et. al (1991). W= Wt - Wo

Keterangan :

$\mathrm{W}=$ pertumbuhan mutlak

$\mathrm{Wt}=$ Bobot bioma Akhir penelitian (gram )

$\mathrm{Wo}=$ Bobot biomassa Berat Awal penelitian $($ gram $)$

\section{b.Pertumbuhan panjang mutlak}

Pertumbuhan panjang mutlak dihitung dengan menggunakan rumus (Effendie 1997) sebagai berikut :

$$
\mathrm{L}=\mathrm{L} 2-\mathrm{L} 1
$$

Keterangan :

L :pertumbuhan panjang mutlak

L2 : Panjang Akhir (cm)

L1 :panjang awal $(\mathrm{cm})$

c.Tingkat Kelangsungan Hidup

Tingkat kelangsungan hidup ikan lele (Clarias sp)dihitung dengan menggunakan rumus sebagai berikut (Sukma, 1987).

$$
\mathrm{SR}=\frac{\mathrm{NT}}{\mathrm{NO}} X 100
$$

Keterangan :

SR : Kelangsungan Hidup

NO : Jumlah Ikan Awal Penelitian

NT : Jumlah Ikan Akhir Penelitian 
d.Kualitas Air

Kualitas air yang diamati pada penelitian ini suhu, pH, DO, amoniak.

\section{Analisis Data}

Data-data yang diperoleh selama penelitian kemudian dianalisis secara statistik dengan menggunakan analisis varian (one-way Anova) untuk mengetahui perbedaan antara perlakuan dan kontrol. Untuk mengetahui signifikan perbedaan rata-rata dengan tingkat kepercayaan $95 \%$ program yang digunakan untuk menganalisis data-data tersebut menggunkan software SPSS 20.0 .

\section{HASIL DAN PEMBAHASAN}

\section{Pertumbuhan Panjang Ikan Lele (Clarias sp)}

Hasil pemeliharaan ikan lele yang diberi perlakuan Probiotik terhadap parameter panjang ikan lele disajikan pada Gambar 1. Berdasarkan gambar 1. terlihat bahwa panjang rata-rata ikan lele pada semua perlakuan yang diberi probiotik EM4 berbeda pada setiap perlakuan.Menurut Effendi (1997) pertumbuhan adalah penambahan ukuran panjang atau bobot ikan dalam waktu tertentu yang dipengaruhi oleh pakan yang tersedia, jumlah ikan, suhu, umur dan ukuran ikan.

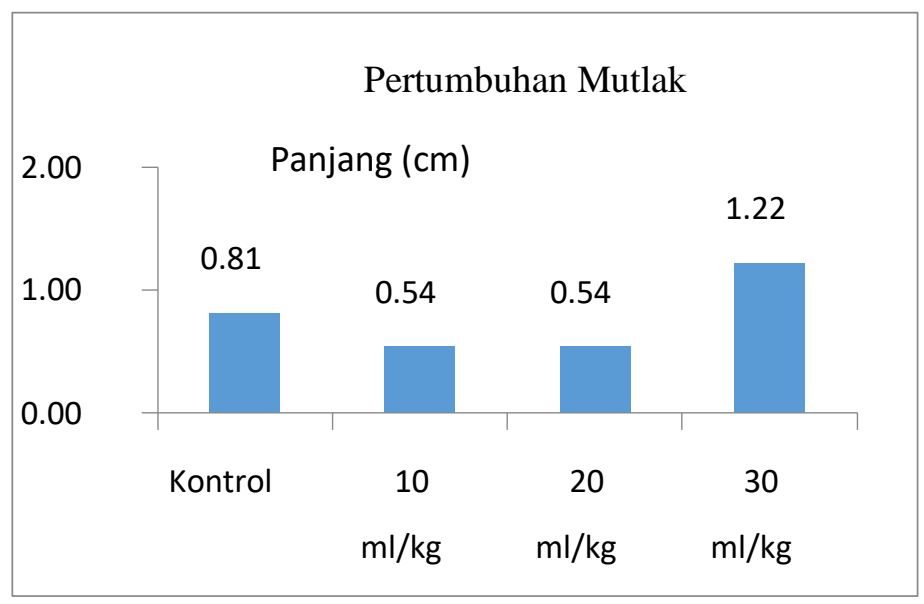

Gambar 1. Panjang rata-rata ikan lele (Clarias sp). Ket:(A) adalah perlakuan kontrol, (B) probiotik dengan dosis $10 \mathrm{ml} / \mathrm{kg}$ pakan, (C) probiotik dengan dosis $20 \mathrm{ml} / \mathrm{kg}$ pakan, (D) probiotik dengan dosis $30 \mathrm{ml} / \mathrm{kg}$ pakan.

Berdasarkan pengujian statistik pada perlakuan dengan pemberian perlakuan probiotik EM4 bahwa data peningkatan panjang ikan lele tidak berbeda nyata dengan kontrol ( $\mathrm{P}>0.05)$. Perlakuan A, B, C, D tidak berbeda nyata, tetapi pada perlakuan D yaitu $(1.22 \mathrm{~cm})$ lebih tinggi dibandingkan dengan perlakuan lainnya, diposisi ke dua perlakuan A (kontrol) yaitu $(0.81 \mathrm{~cm})$, 
sedangkan posisi ke tiga perlakuan B yaitu $(0.54 \mathrm{~cm})$, dan yang terakhir pertumbuhan rata-rata terendah perlakuan $\mathrm{C}(0,54 \mathrm{~cm})$. Panjang rata-rata tertinggi adalah perlakuan $\mathrm{D}$ diperkirakan karena probiotik EM4 yang ditambahkan pada pakan buatan berkerja efektif untuk pertumbuhan panjang ikan lele dengan meningkatkan nafsu makan dan meningkatkan penyerapan pakan pada sistem pencernaan ikan lele.

Mulyadi (2011) proporsi jumlah koloni bakteri probiotik dalam pakan menyebabkan aktivitas bakteri probiotik dapat berkerja secara maksimal dalam pencernaan ikan, sehingga daya cerna ikan menjadi lebih tinggi dalam menyerap sari-sari makanan dan menghasilkan pertumbuhan yang lebih baik. Sesuai dengan pernyataan CortezJacinto, et al., (2005) yang menjelaskan bahwa laju pertumbuhan berkaitan erat dengan pertambahan panjang tubuh yang berasal dari pakan yang dikonsumsi. Hal ini dibuktikan dengan perlakuan A (kontrol ) pertumbuhan panjangnya rendah dibandingkan dengan perlakuan D yang diberi probiotikEM4 $30 \mathrm{ml} / \mathrm{kg}$. Perlakuan A lebih baik dibandingkan dengan perlakuan B dan C dimungkinkan karena probiotik EM4 yang diberikan belum cukup optimal untuk pertumbuhan panjang ikan lele.

\section{Pertumbuhan bobot ikan lele (Clarias sp).}

Pertumbuhan bobot biomassa harian benih ikan Lele (Clarias $\mathrm{sp)}$ ) selama 30 hari sesuai perlakuan pemberian probiotik EM4 dengan dosis yang berbeda pada benih ikan Lele (Clarias sp) menunjukkan pertumbuhan rata - rata bobot biomassa harian yang berbeda pula. Pertumbuhan bobot biomassa harian benih ikan lele tertinggi ditunjukkan pada pemberian probiotik EM4 perlakuan C (20 ml)dilanjutkan dengan pemberian probiotik perlakuan D (30 ml), kemudian perlakuan A (kontrol) dan B (10 ml). Hadjani dan Widodo (2010) dalam Muhammad et al (2014) menyatakan bahwa pertumbuhan sebagai pertambahan volume dan berat dalam waktu tertentu. Pertumbuhan ikan lele disebabkan oleh beberapa faktor terutama adanya pasokan energi dari pakan. Kelebihan energi yang dibutuhkan untuk pemeliharaan dan aktifitas tubuh dimanfaatkan untuk pertumbuhan. Laju pertumbuhan harian berfungsi untuk menghitung presentase pertumbuhan berat ikan. Berdasarkan hasil penelitian menunjukkan bahwa rata-rata pertumbuhan harian benih ikan lele cenderung meningkat dengan perlakuan penambahan proobiotik yang dibuat dari bahan pakan dengan dosis $15 \mathrm{ml} / \mathrm{kg}$.

Effendie (1997) menyatakan bahwa pertumbuhan adalah penambahan ukuran panjang atau bobot ikan dalam kurun waktu tertentu yang dipengaruhi oleh pakan yang tersedia, jumlah ikan, suhu, umur dan ukuran ikan. Hasil pemeliharaan ikan lele yang diberi perlakuan probiotik 
EM4 terhadap bobot rata-rata ikan lele dapat dilihat pada Gambar 2. Seiring dengan bertambahnya waktu pemeliharaan, bobot rata-rata ikan lele pada perlakuan yang diberi probiotik EM4 tampak lebihtinggidibandingkan kontrol.

Berdasarkan pengujian statistik pada perlakuan dengan pemberian perlakuan probiotik bahwadata peningkatanbobotikanleletidakberbeda nyata dengan kontrol $(\mathrm{P}>0.05)$. Pada Gambar 2 dapat dilihat bahwa pertumbuhan rata-rata bobot ikan pada perlakuan D yaitu (2,22 gr) lebih tinggi dibandingkan dengan perlakuan lainnya. Diikuti perlakuan A yaitu (2,19 gr) selanjutnya perlakuan C (1,85 gr) dan perlakuan terendah adalah perlakuan B yaitu (1.72 gr). Bobot rata-rata tertinggi adalah perlakuan D diduga karena probiotik EM4 yang ditambahkan pada pakan bekerja optimal untuk memacu pertumbuhan berat ikan lele dan meningkatkan nafsu makan dan meningkatkan efesiensi penyerapan pakan di sistem pencernaan ikan lele. Hal ini sesuai dengan pernyataan Suzer et al., (2008) melaporkan bahwa benih yang diberi probiotik dapat menunjukan pertumbuhan yang lebih cepat dibandingkan dengan tanpa pemberian probiotik.

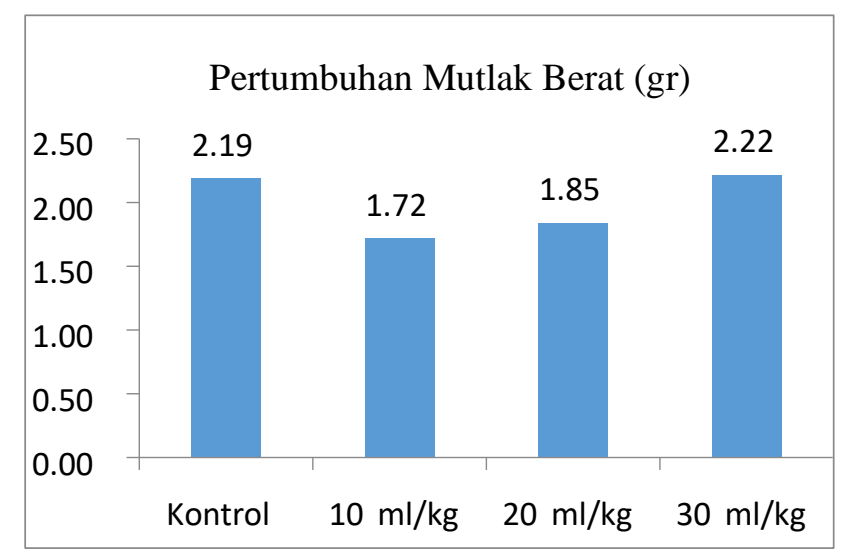

Gambar 4. Bobot rata-rata ikan lele (Clarias sp). Ket: (A) adalah perlakuan kontrol, (B) probiotik dengan dosis $10 \mathrm{ml} / \mathrm{kg}$ pakan, (C)probiotik dengan dosis $20 \mathrm{ml} / \mathrm{kg}$ pakan, (D) probiotik dengan dosis $30 \mathrm{ml} / \mathrm{kg}$ pakan.

Menurut Mulyadi (2011) proporsi jumlah koloni bakteri probiotik dalam pakan menyebabkan aktivitas bakteri probiotik dapat berkerja secara maksimal dalam pencernaan ikan, sehingga daya cerna ikan menjadi lebih tinggi dalam menyerap sari-sari makanan dan menghasilkan pertumbuhan yang lebih baik. Sesuai dengan pernyataan Cortez Jacinto, et al., (2005) yang menjelaskan bahwa laju pertumbuhan berkaitan erat dengan pertambahan panjang tubuh yang berasal dari pakan yang dikonsumsi. Hal ini dibuktikan dengan perlakuan D 
pertumbuhan panjangnya lebih tinggidibandingkan dengan perlakuan yang diberi probiotik EM4 yang lain.

\section{Kelangsungan Hidup Ikan Lele (Clarias sp)}

Kelangsungan merupakan suatu presentase organisme yang hidup pada akhir pemeliharaan dari jumlah organisme yang ditebar pada saat pemeliharaan dalam suatu wadah. Berdasarkan hasil penelitian, diperoleh hasil perhitungan bahwa tingkat kelangsungan hidup pada perlakuan A dan D 100\% sedangkan perlakuan B dan C yaitu 86\% (Gambar 3). Menurut Irianto (2003) dalam Jariyah et al. (2013) mikroba probiotik merupakan mikroba yang aman dan relatif menguntungkan dalam saluran pencernaan, mikroba ini menghasilkan zat yang tidak berbahaya bagi ikan tetapi justru menghancurkan mikroba patogen pengganggu sistem pencernaan sehingga ikan akan sehat dan terhindar dari penyakit yang dapat membuat presentase tingkat kelangsungan hidup menurun .

Kualitas air serta perbandingan antara jumlah makanan dan kepadatannya. Padat tebar yang terjadi dapat menjadi masalah penyebab rendahnya tingkat kelangsungan hidup suatu organisme, terlihat kecendrungannya bahwa makin meningkat padat tebar ikan maka tingkat kelangsungan hidupnya akan makin kecil (Allen, 1974). Pengukuran kelangsungan hidup ikan lele diukur pada penelitian ini untuk mengetahui pengaruh probiotik terhadap respon ikan lele. Berdasarkan pengukuran kelangsungan hidup ikan lele pada akhir penelitian dengan pemberian probiotik EM4 dengan dosis yang berbeda disetiap perlakuan dapat dilihat pada Gambar 3.

Tingkat kelangsungan

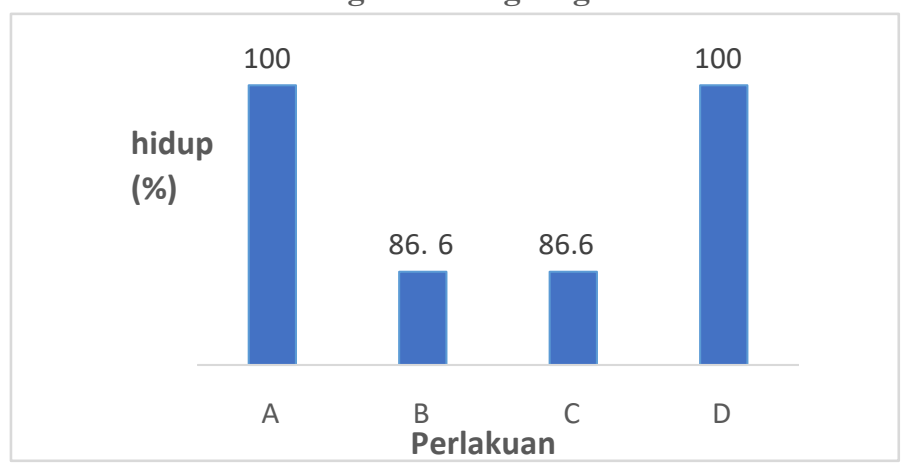

Gambar 3. Tingkat kelangsungan hidup (\%) ikan lele (Clarias sp). Ket: (A) adalah perlakuan kontrol, (B) probiotik dengan dosis $10 \mathrm{ml} / \mathrm{kg}$ pakan, (C) probiotik dengan dosis 20 $\mathrm{ml} / \mathrm{kg}$ pakan, (D) probiotik dengan dosis $30 \mathrm{ml} / \mathrm{kg}$ pakan. 
Berdasarkan gambar3terlihat bahwa tingkat kelangsungan hidup paling tinggi ada pada perlakuan A dan D yaitu (100\%) dan tingkat kelangsungan hidup paling rendah perlakuan B dan C yaitu (86,66 \%). Berdasarkan pengujian statistik pada perlakuan dengan pemberian perlakuan probiotik EM4 bahwa data survival rate (SR) pada ikan lele berbeda nyata dengan control $(\mathrm{P}<0,05)$ dan perlakuan $\mathrm{D}$ dan $\mathrm{A}$ berbeda nyata dengan perlakuan $\mathrm{B}$ dan $\mathrm{C}$. Berdasarkan penjelasan tersebut dapat dilihat bahwa survival rate (SR) yang tertinggi ada pada perlakuan A (kontrol) dan perlakuan D. Dilihat dari nilai kelangsungan hidup ikan lele uji, pada dosis yang tinggi D yaitu $(30 \mathrm{ml})$ justru mengalami tingkat kelangsungan hidup yang baik. Wang et al., 2008 probiotik yang dicampur pada pakan dengan dosis optimal,dapat meningkatkan kelangsungan hidup ikan lele .Perlakuan B dan C memiliki tingkat kelangsungan hidup lebih rendah dari pada perlakuan A yang merupakan kontrol mungkin dikarenakan dosis yang diberikan belum cukup optimal sehingga tidak memiliki efek yang signifikan terhadap tingkat kelangsungan hidup ikan lele.

\section{Parameter Kualitas Air}

Kualitas air merupakan faktor penting dalam budidaya ikan kerena diperlukan sebagai media hidup ikan. Beberapa faktor parameter fisika kimia yang dapat mempengaruhi hidup ikan adalah suhu, oksigen terlarut, $\mathrm{pH}$ dan amoniak (Weatherley, 1972). Kualitas air yang kurang baik dapat menyebabkan ikan cepat terserang penyakit.

Tabel 1. Kisaran parameter kualitas air awal pemeliharaan dan hasil penggukuran kualitas air pada akhir penelitian.

\begin{tabular}{ccccc}
\hline Perlakuan & Suhu $\left({ }^{0} \mathrm{C}\right)$ & $\mathrm{DO}(\mathrm{Mg} / \mathrm{L})$ & $\mathrm{p} \mathrm{H}$ & Amoniak $(\mathrm{Mg} / \mathrm{L})$ \\
\hline $\mathrm{A}$ & 24 & $4.39-5.88$ & $7-8$ & 0.48 \\
& 29 & & & \\
$\mathrm{~B}$ & 24 & $4.88-5.47$ & $6-7$ & 0.31 \\
& 29 & & & \\
$\mathrm{C}$ & 24 & $4.70-6.00$ & 7 & 0.12 \\
& 29 & & & \\
$\mathrm{D}$ & 24 & $4.75-5.07$ & $7-8$ & 0.16 \\
& 29 & & & \\
\hline
\end{tabular}

Ikan lele mudah beradaptasi dengan lingkunganya yang tergenang air dan bila sudah dewasa dapat diadaptasikan pula dengan lingkungan perairan yang mengalir (Puspowardoyo dan Djarijah, 2002). Suhu merupakan faktor yang mempengaruhi laju metabolisme dan kelarutan gas 
dalam air (Zonneveld et al.,1991). Pada umumnya ikan lele hidup normal pada kandungan oksigen terlarut 4-6 mg/L, jika persediaan oksigen dibawah 20\% dari kebutuhan normal, lele akan lemas dan menyebabkan kematian (Murhananto, 2002). Kadar pH yang baik untuk ikan lele (Clarias $s p$ ) adalah 6,5-9, kadar $\mathrm{pH}$ yang kurang dari 5 sangat buruk bagi ikan lele karena bisa menyebabkan penggumpulan lendir pada ingsang. Sedangkan kadar $\mathrm{pH}$ yang bernilai 9 lebih akan menyebabkan berkurangnya nafsu makan ikan lele (Himawan, 2008). Amoniak merupakan hasil ahir metabolisme protein dan dalam bentuknya yang tidak terionisasi yanga sangat rendah. Kosentrasi amoniak terlarut itu sendiri didalam air bergantung pada $\mathrm{pH}$ dan suhu (masser et al., 1999).

Pengamatan parameter kualitas air untuk Suhu, oksigen, terlarut (DO) dan $\mathrm{pH}$ dilakukan 2 kali sehari yaitu pagi dan sore hari, sedangkan pengukuran amoniak dilakukan 2 kali di awal dan akhir penelitian. Berdasarkan dari Tabel 1. dapat dilihat bahwa suhu pada semua perlakuan selama penelitian berkisar $25-29^{\circ} \mathrm{C}$, sehingga dapat dikatakan bahwa suhu sudah optimal untuk pertumbuhan benih ikan lele, seperti yang dijelaskan oleh Cahyono (2009) bahwa suhu air yang optimal untuk benih ikan lele $24-30^{\circ} \mathrm{C}$.

Nilai oksigen terlarut (DO) pada setiap perlakuan berbeda. Pada perlakuan A yaitu 4.39$5.88 \mathrm{mg} / \mathrm{L}$, perlakuan B yaitu 4.88-4.47 mg/L, perlakuan C yaitu 4.70-6.00 mg/L dan perlakuan D yaitu 4.75-5. $07 \mathrm{mg} / \mathrm{L}$. Kisaran DO tersebut termasuk ke dalam kisaran optimal untuk kelangsungan hidup benih ikan lele, hal ini sesuai dengan pernyataan Murhananto (2002) pada umumnya ikan lele hidup normal pada kandungan oksigen terlarut 4-6 mg/L. Sedangkan nilai pH selama penelitian pada setiap perlakuan berbeda, perlakuan A yaitu 7-8, perlakuan B yaitu 6-7, perlakuan $\mathrm{C}$ yaitu 7 dan perlakuan $\mathrm{D}$ yaitu 7-8. Kisaran nilai $\mathrm{pH}$ tersebut masih dalam kisaran yang optimal untuk kelangsungan hidup benih ikan lele, hal ini sesuai dengan pernyataan Barus (2002) nilai $\mathrm{pH}$ yang ideal bagi kehidupan organisme air pada umumnya terdapat antara 6.5-9.

Kadar amoniak pada setiap perlakuan memiliki nilai yang berbeda, pada perlakuan A yaitu $0.48 \mathrm{mg} / \mathrm{L}$, perlakuan B yaitu $0.31 \mathrm{mg} / \mathrm{L}$, perlakuan C yaitu $0.12 \mathrm{mg} / \mathrm{L}$ dan perlakuan $D$ yaitu $0.16 \mathrm{mg} / \mathrm{L}$. Kisaran nilai amoniak tersebut masih dalam kisaran yang optimal untuk kelangsungan hidup benih ikan lele, hal ini sesuai dengan pernyataan Khairuman dan Amri (2002) bahwa kandungan maksimum amoniak dalam suatu wadah pemeliharaan untuk benih ikan lele yang masih dapat ditolerir adalah $1 \mathrm{mg} / \mathrm{L}$. 


\section{SIMPULAN}

Berdasarkan penelitian dapat disimpulkan bahwa dengan pemberian probiotik pada ikan lele dengan berbagai dosis tidak berbeda nyata pada setiap perlakuan ,tetapi perlakuan D pakan pellet dengan Dosis probiotik $30 \mathrm{ml} / \mathrm{kg}$ mengalami pertumbuhan berat dan pertumbuhan panjang yang lebih tinggi yaitu (2.22 gr dan $1.22 \mathrm{~cm}$ ) jika dibandingkan dengan perlakuan lainnya.

\section{DAFTAR PUSTAKA}

Ahmadi, H., Iskandar., Kurniawati., N., (2012). Pemberian Probiotik dalam Pakan Terhadap Pertumbuhan Ikan Lele (Clarias graprienus)

Allen. (1974). Ikan lele. (http://Www.Docstoc.Com/Docs/19916828/ikan/-lele.).

Amri, K., Khairuman. (2008). Buku Pintar Budidaya 15 Ikan Konsumsi Agromedia. Jakarta.

Arief, M., et.al. (2014). Pengaruh Pemberian Probiotik Berbeda Pada Pakan Komersial Terhadap Pertumbuhan dan Efisiensi Pakan Ikan Lele Sangkuriang (clarias Gariepinus). Surabaya.

Barus, T. A. (2002). Pengantar Limnology. Universitas Sumatra Utara. Medan.

Boyd, C. E. (1990). Water Quality in Ponds for Aquaculture. Aubum University. Alabama.

Cahyono, B. (2009). Budidaya Lele Dan Betutu (Ikan Langka Bernilai Tinggi). Pustaka Mina. Jakarta .

Dhingra, M.M. (1993). Probiotic In Poultry Diet Livestock Production And Management. Sania Enterprises Indore, India.

Djoko. (2006). Lele Sangkuriang Alternatif Kualitas di Tanah Priangan. Jakarta.

Effendie, I. N.J. Bugri, Dan Widanarni. (2006). Pengaruh Padat Penebaran Terhadap Kelangsungan Hidup Dan Pertumbuhan Benih Ikan Gurami Ospheronemus Gourami. Ukuran 2 Cm. Jurnal Akuakultur Indonesia.

Effendie, M. I. (1979). Metode Biologi Perikanan. Bogor: Yayasan Pustaka Nusantama.

Effendie, M. I. (1997). Biologi Perikanan.Bogor: Yayasan Pustaka Nusantama.

Fajar, M. (1988). Budidaya Perairan Intensif. Universitas Brawijaya Malang.

Fuller, R. (1987). A Review, Probiotics In Man And Animals.JAppI Bacteriol, 66:355-37.

Ghufran. M, Kordi K.H. (2010). Budidaya Ikan Lele di Kolam Terpal. Yogyakarta : Lily Publisher.

Guarner F., Khan A.G., Garisch J., Eliakim R., Gangl A., Thomson A., et al. (2008). Probiotic and Prebiotics.

Gunawan. RGB. (2015). Membuat Sendiri Pakan Ikan Murah Dan Praktis. PT Agromedia Pustaka. Jakarta.

Gurisna. (2008). Buku Budidaya Ikan Jilid 1 untuk SMA. Direktorat Pembinaan Sekolah Menengah Kejuruan. Jakarta.

Himawan, (2008). Habitat Atau Lingkungan Hidup Ikan LeleAdalah Air tawar

Himawan. (2008). Budidaya Lele Sangkuriang.Http://Indonesia.Com/F/18253Budidaya -LeleSangkuriang-Clarias-Sp/.

Irianto, A. (2003). Probiotik Akuakultur. Gaja Mada University Press. Yogyakarta. 
Irianto, A. (2007). Potensi Mikroorganisma: diatas langit ada langit. Ringkasan Orasi Ilmiah di Fakultas Biologi Universitas Jenderal Sudirman Tanggal 12 mei.

Jariyah et.al. (2009). Mikroba Probiotik Merupakan Mikroba Yang Aman dan Relatif Mengguntungkan Dalam Saluran Pencernaan.

Khairuman Dan K. Amri. (2009). Peluang Usaha Dan Teknik Budidaya Lele Sangkuriang.Pt. Gramedia Pustaka Utama. Jakarta.

Lovell, T. (1989). Nutrition And Feeding Of Fish. Auburn University, New York.

Lukito, (2002). Sirip Dada Lele Dilengkapi Dengan Patil.

Lukito, A. M. (2002). Lele Ikan Berkumis Paling Populer. Agromedia. Jakarta.

Maryanto, R. Ubaidillah. (2003). Manajemen Bioregional Jabotabek: Profil Dan Strategi Pengelolahan Situ, Rawa Dan Danau. Pusat Penelitian BiologiLembaga Ilmu Pengetahuan Indonesia. Bogor.

Masser, M.P., J. Rakocy, and T.M. Lassordo. (1999). Recirculating Aquaculture Tank Production Systems : Management of Recirculating Systems. SRAC Pub. No 452. Http:// www. Texasefc. Tamu. Edu/ pubs/ efish/ 452 fs. Pdf. Tanggal Kunjungan.

Mudjiman, A. (2000). Makanan Ikan. Penebar Swadaya. Jakarta.

Muhammad Arief, Nur Fitriani, Sri Subekti, (2014). Pengaruh Pemberian Probiotik Berbeda Pada Pakan Komersil Terhadap Pertumbuhan dan Efisiensi Pakan Ikan Lele Sankuriang (Clarias sp.). Fakultas Perikanan dan Kelautan Universitas Airlangga. Kampus C Mulyorejo. Surabaya.

Murhananto. (2002).Pembesaran Lele Dumbo di Perkarangan.PT Agromedia Pustaka.Tangerang.

Muyadi, A. E. (2011). Pengaruh Pemberian Probiotik Pada Pakan Komersial Terhadap Laju Pertumbuhan Benih Ikan Patin Siam (Pangasius Hyphothalamus). Skripsi. Fakultas Perikanan Dan Ilmu Kelautan. Unpad Jatinangor.

Puspowardoyo, H. Dan Djarijah, A. (2002). Pembenihan dan Pembesaran lele Sangkuriang hemat air. Kanisius. Yogyakarta.

Putra, 1. (2010). Efektifitas Penyebaran Nitrogen dengan Medium Filter Berbeda Pada Pemeliharaan Ikan Nila (Oreochromis niloticus) dalam Sistem Resirkulasi.Tesis. Insitut Pertanian Bogor. Bogor. 67 Him.

Santoso. (2013). Efektifitas Penambahan Probiotik Pada Pakan Komersial Dengan Dosis Yang Berbeda Terhadap Pertumbuhan Benih Ikan Lele Dumbo (Clarias Gariepinus). Universitas Borneo Tarakan.

Setiawan, B. (2009). Pengaruh Padat Penebaran 1, 2 dan 3 Ekor/L Terhadap Kelangsungan Hidup Dan pertumbuhan Benih Ikan Maanvis pterophyllum Scalare. Fakultas Perikanan dan Ilmu Kelautan Insitut Pertanian Bogor.

Sofyan, O. (2003). Kajian Probiotik Ab (Aspergillus Niger Dan Basillus sp.) Sebagai Imbuhan Ransum dan Implikasi Efeknya Terhadap Mikroflora Usus Serta Penampilan Produksi Ayam Petelur. Disertasi. Program Pascasrjana Unpad. Bandung.

Susanto, H. (2014). Budidaya 25 Ikan di Perkarangan.Penebar Swadaya. Jakarta.

Suyanto, R1999.Budidaya Lele. Penebar Swadaya. Jakarta.

Suzer, C., Coban., H.O, kamaci., S, Saka., \& K, Firat (2008). Lactobacillus spp. Bacteria as probiotic in Gilthead sea Bream(Sparus Auratus, L.) Larvae: Effect on Grownth Performance and Degestive Enzyme Activites Aquaculture. 
Wang, Y. (2008). Use Of Probiotics Bacillus Coagulans, Rhodopeseumonas Palustris and Lactobacillus Achidiophilus As Growth Promoters In Grass Carp. Aquaculture Nutrition.

Wardoyo, S.T.H. (1975). Pengelolahaan Kualitas Air. Insitut Pertanian Bogor. 41h.

Weatherley, A. H. (1972). Growht And Ecology Of Fish Populations. Academy Press, London.

Zonneveld, N., E. A. Huisman dan J. H. Boon. (1991). Prinsip-Prinsip budidaya ikan. Terjemahan . PT. Gramedia Pustaka Utama. Jakarta.

Yousefian et al. (2009). Probiotik Dalam Akuakultur Berperan Dalam Meningkatkan Laju Pertumbuhan. 